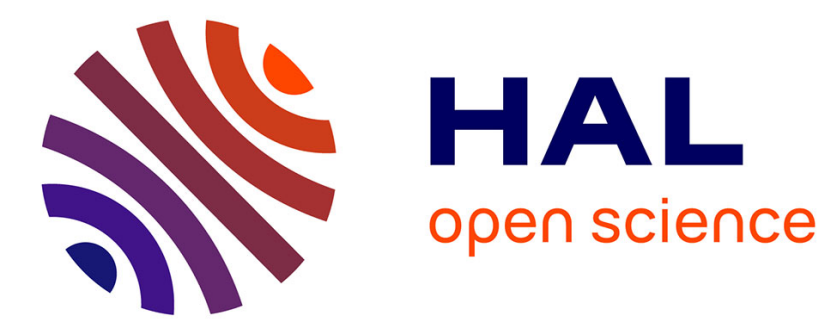

\title{
Heterosis, genetic effects and value of F2s and doubled-haploid lines in barley breeding
}

Leila Hanifi-Mekliche, André Gallais

\section{To cite this version:}

Leila Hanifi-Mekliche, André Gallais. Heterosis, genetic effects and value of F2s and doubled-haploid lines in barley breeding. Agronomie, 1999, 19 (6), pp.509-520. hal-00885949

\section{HAL Id: hal-00885949 \\ https://hal.science/hal-00885949}

Submitted on 1 Jan 1999

HAL is a multi-disciplinary open access archive for the deposit and dissemination of scientific research documents, whether they are published or not. The documents may come from teaching and research institutions in France or abroad, or from public or private research centers.
L'archive ouverte pluridisciplinaire HAL, est destinée au dépôt et à la diffusion de documents scientifiques de niveau recherche, publiés ou non, émanant des établissements d'enseignement et de recherche français ou étrangers, des laboratoires publics ou privés. 
(C) Inra/Elsevier, Paris

\title{
Original article
}

\section{Heterosis, genetic effects and value of $F_{2} s$ and doubled-haploid lines in barley breeding}

\author{
Leila Hanifi-Mekliche ${ }^{\mathrm{a}}$, André Gallais ${ }^{\mathrm{b}^{*}}$ \\ a Département de phytotechnie, Institut national agronomique, El Harrach, Alger, Algeria \\ ' Station de génétique végétale, Inra-UPS-INAPG, Ferme-du-Moulon, 91 190, Gif-sur-Yvette, France
}

(Received 19 May 1998; accepted 16 May 1999)

\begin{abstract}
To study the potential of $\mathrm{F}_{1}, \mathrm{~F}_{2}$ and doubled-haploid lines in six-row barley, three connected experiments were developed: i) study of a complete $8 \times 8$ diallel; ii) comparison of $F_{1}, F_{2}$ and their parents for three crosses from the diallel; ii) comparison of 53 doubled-haploid lines from a cross to their parents, $F_{1}$ and $F_{2}$. In the diallel experiment, the average of all $F_{1}$ for grain yield was equal to the average of the parents. The best cross was only $3.2 \%$ better than the best parent. However, for main ear grain weight mean heterosis was $13 \%$. It was negative $(-11 \%)$ for straw yield. There was a great variation among crosses. General combining ability (GCA) was a main component of such a genetic variation for all traits studied. Resistance to mildew, thousand grain weight and heading date were the most additive and grain and straw yield the least additive traits. The study of $F_{2}$ showed that, for grain yield, heterosis was reduced more than expected. This is interpreted as being mainly the result of intergenotypic competition between $F_{2}$ plants. However, epistasis is possible, and it was detected for yield and its components, by the comparison of DH lines to their mid-parent. The comparison of DH lines with $F_{1}$ showed that the genetic advantage obtained in $F_{1}$ for grain yield and its components can be fixed at the level of doubled-haploid lines. Nevertheless, the possible negative effect of recombination and epistasis can lead to the use of haplodiploidisation after the $F_{1}$ generation. (@ Inra/Elsevier, Paris.)
\end{abstract}

\section{barley / heterosis / $\mathbf{F}_{2}$ / doubled haploid / competition / epistasis}

Résumé - Hétérosis, effets génétiques et valeur des $F_{2}$ et des lignées haplodiploïdes chez l'orge (Hordeum vulgare L.). Pour étudier l'intérêt comparé des hybrides $\mathrm{F}_{1}$, des $\mathrm{F}_{2}$ et des lignées chez l'orge à six rangs, trois expériences ont été réalisées: un croisement diallèle complet entre huit parents, une comparaison de trois $F_{2}$ à leur $F_{1}$ et l'étude de 53 lignées obtenues par haplodiploidisation à partir d'un croisement. Au niveau du diallèle, le rendement en grains des $F_{1}$ était en moyenne égal à celui des parents. Le rendement du meilleur hybride n'a été supérieur que de $3.2 \%$ au meilleur parent. Pour le rendement en grain du maître brin, l'hétérosis a été de $13 \%$. Il a été négatif pour le rendement en paille $(-11 \%)$. Une grande variation est apparue entre croisements. L'aptitude générale à la combinaison (AGC) est la com-

Communicated by André Gallais (Gif-sur-Yvette)

* Correspondence and reprints

gallais@moulon.inra.fr 
posante majeure de cette variation pour tous les caractères étudiés. La résistance à l'oïdium, le poids de mille grains et la précocité d'épiaison apparaissent comme les caractères les plus additifs et le rendement en grain et en paille comme les moins additifs. La comparaison de la $\mathrm{F}_{2}$ à la $\mathrm{F}_{1}$ et au parent moyen a montré que l'hétérosis pour le rendement, était plus réduit qu'attendu. Cela est interprété comme étant principalement le résultat de la compétition entre génotypes au sein de la génération $\mathrm{F}_{2}$. Cependant cela peut être dû à des effets d'épistasie, d'ailleurs détectés pour le rendement et ses composantes, par la comparaison des lignées $\mathrm{HD}$ et de leurs parents. La comparaison des lignées $\mathrm{HD}$ avec la $\mathrm{F}_{1}$ montre que l'hétérosis obtenu en $\mathrm{F}_{1}$, peut être fixé pour le rendement et ses composantes. Cependant, l'effet négatif possible de la recombinaison et de l'épistasie peut conduire à envisager l'haplodiploidisation après la génération $F_{1}$. (ㄷ) Inra/Elsevier, Paris.)

orge / hétérosis / $\mathrm{F}_{2}$ / haplodiploidisation / compétition / épistasie

\section{Introduction}

In autogamous plants, heterosis is less important than in allogamous plants, but it can still be relatively important. In barley (Hordeum vulgare L.), some results show that the grain yield heterosis can reach from $20 \%[8]$ to more than $100 \%[6,21]$ according to the material used [24], the type of sowing (dense sowing or space-planted) and the environment (high or poor fertility) [20].

If heterosis is important, $F_{1}$ hybrids could be justified as type of cultivar, instead of inbred lines. Then, breeders could be interested in the prediction of the $F_{1}$ value in order to reduce the work required by the large number of crosses necessary to identify the best crosses. As heterosis is related to genetic distance [26], different indicators of genetic divergence could be used for the $F_{1}$ value prediction. Parental divergence, estimated by Mahalanobis $\mathrm{D}^{2}$ from phenotypic data could be used. However, inconsistent results have been obtained. Guo et al. [16] obtained a highly significant correlation between $\mathrm{D}^{2}$ and heterosis in common wheat over 2 years. In contrast, in maize, Moll et al. [29] found that heterosis manifested in crosses of the most genetically divergent varieties was lower than heterosis expressed between varieties considered to be less genetically distant. In wheat, Singh and Behl [35] and Picard et al. [32] did not find any correlation between heterosis and $\mathrm{D}^{2}$. Apparently, crosses between extremely divergent parents create a situation where the harmonious functioning of alleles is disrupted [17]. To predict specific combining ability in Pennisetum typhoides, Marchais [27] used the Hanson and Casas distance [18], and showed a relatively close relationship between such a distance and specific heterosis for 11 out of 12 traits studied. However, the value of such a distance has not been confirmed in other studies [27]. The use of molecular markers could contribute to the improvement of the measurement of genetic distance and hence possibly to the prediction of heterosis [4]. This is clearly demonstrated by the results of Xiao et al. [38], showing a high correlation between heterosis and molecular distance in rice. In fact, the prediction of heterosis remains an open question.

A main problem for the development of hybrids in cereals, such as barley and wheat, will be the difficulty or cost of crossing control, either by nucleo-cytoplasmic male sterility, with good fertility restoration, or by the use of chemical hybridising agents. To avoid such a problem, it has already been proposed in wheat to exploit heterosis at the $\mathrm{F}_{2}$ level $[2,24]$. This will be justified if inbreeding depression from $F_{1}$ to $F_{2}$ is lower than expected. This could be the case for some crosses due to the effect of intergenotypic competition. Finally, it may be questioned whether the use of heterosis is justified in comparison to the development of pure lines.

Therefore, using six-rowed barley (Hordeum vulgare L.) as material, the objectives of the present study were:

- to see the potential value of $F_{1}$ and to analyse $F_{1}$ value and heterosis in terms of genetic effects; 
- to study different predictors of cross values and heterosis, using per se value and the Hanson and Casas distance;

- to investigate on the one hand the possibility of using heterosis at the $\mathrm{F}_{2}$ level, and on the other the possibility to derive pure lines as good as the best single-cross hybrids, through the study of doubled-haploid (DH) lines from one cross.

\section{Materials and methods}

\subsection{Plant material and designs}

Heterosis was studied with a $\mathrm{F}_{1} 8 \times 8$ diallel cross with reciprocal crosses and the parents. The cultivars used in this diallel were of different origins (table I). Jaidor and Motan are issued from the same pedigree and Prato and CM67 are also related. The crosses studied to compare the magnitude of heterosis in $\mathrm{F}_{1}$ and $\mathrm{F}_{2}$ were Motan/CM67, Prato/CM67 and Apizaco/Prato. Fiftythree doubled-haploid (DH) lines were derived by the 'bulbosum' method from the cross Motan/CM67.

The $F_{1}$ were studied in 1986 . The comparison of $F_{1}$ with $F_{2}$ was performed in 1988 for Prato/CM67 and Apizaco/Prato hybrids and in 1991 for Motan/CM67 cross. DH lines were studied in 1991. The parental cultivars were included in each trial. A randomised block design with three replicates was used at I.N.A. of Algiers in the three trials (1986, 1988 and 1991). Each plot consisted of a single row of $1 \mathrm{~m}$ in length with ten grains per row in 1986 and 30 grains per row in 1988 and 1991, for $F_{1}$, parental and DH lines, while the $F_{2}$ were grown on three rows each. Overall, the 1988 and
1991 trials included 7 and 56 treatments, respectively. To compare $F_{1}$ and $F_{2}$, the different means were calculated on the basis of 30 plants per block, for the parents and $F_{1}$. For the $F_{2}$, the mean was calculated on the basis of 46 plants/block/cross for the 1988 trial and 72-79 plants/block for the 1991 trial.

Such micro-plot designs were chosen owing to the small quantity of available seeds for $\mathrm{F}_{1}$ crosses and $\mathrm{DH}$ lines. For $F_{1}$, parents and $\mathrm{DH}$ lines, the evaluation of different quantitative traits, such as grain yield and related traits, in single-row micro-plots could be biased by effects of inter-row competition [15]; an acceptable agronomic estimation of grain yield would have required multi-row micro-plots of at least $2 \mathrm{~m}^{2}$. The problem is different for the $F_{2}$ because it is an heterogeneous generation, and then intergenotypic competition within the row was present. The design was more justified for studying grain yield in the presence of competition than for a genetic interpretation of heterosis. For all generations, in such micro-plots, border effects have undoubtably been important.

\subsection{Traits studied in the trials}

Grain yield/plant, straw yield/plant, harvest index, ear number/plant, main ear grain weight, grain number/ear, thousand grain weight, ear length, straw height and internode number were studied in all trials. Heading date was studied in 1986 and 1991 trials, whereas 'vertical' development of powdery mildew symptoms was only studied in 1986 . Heading was noted when $50 \%$ of ears reached the stage. For mildew, the scale of vertical progression varied from 0 to 5 . All measurements or observations on different traits were made on individual plants.

Table I. Origin of the parents used in the $8 \times 8$ diallel mating.

\begin{tabular}{lll}
\hline Parents & Origin & Pedigree \\
\hline Jaidor & France & Rika.Baladi16* Rika]33 / EMA 1038 // Robur \\
Motan & France & Rika.Baladi 16*Rika]33 / EMA 1038 // Robur \\
Beecher & USA & Atlas/Vaughn (1940) \\
California Mariout 67 (CM67) & USA & $2 *$ California Mariout / CI237 // Club Mariout \\
Prato & USA & CM67 / 3* Briggs / 4 / Briggs * 4 / 3 / Cali. \\
Apizaco & Mexico & Promesa / Toluca \\
Ensenada & Mexico & local cultivar \\
Saïda & Algeria & local cultivar \\
\hline
\end{tabular}




\subsection{Analysis of general and specific heterosis of $F_{1}$ diallel}

The Griffing analysis method 3, i.e. with reciprocal crosses but without parents [12], was first applied. According to this analysis, the average value of a cross between two lines $\mathrm{i}$ and $\mathrm{j}$ is broken down as follows:

$$
Y_{i j}=\mu+g_{i}+g_{j}+s_{i j}
$$

where $g_{i}$ is the general combining ability (GCA) of line $i$ and $s_{i j}$ is the specific combining ability (SCA) of lines $\mathrm{i}$ and $\mathrm{j}$.

Then, general and specific heterosis were studied according to the model developed by Eberhart and Gardner [5]:

$$
\begin{aligned}
& Y_{i j}=v+1 / 2 v_{i}+1 / 2 v_{j}+h_{i j} \\
& Y_{i i}=v+v_{i}
\end{aligned}
$$

$v$ is the mean of the parents and $v_{i}$ the centred value of the line $\mathrm{i}$.

$$
h_{i j}=h+h_{i}+h_{j}+s_{i j}
$$

where $h$ is the average heterosis of all lines used in the trial, $h_{i}$ and $h_{j}$ are the general heterosis of lines $i$ and $\mathbf{j}$, respectively, and $s_{i j}$ is the specific heterosis which is equal to the specific combining ability (SCA).

GCA can be related to $h_{i}$ and $v_{i}: g_{i}=h_{i}+1 / 2 v_{i}$ and thus, $h_{i}=g_{i}-1 / 2 v_{i}$.

From this expression a $t$-test was developed for parental heterosis.

\subsection{Determination of the $F_{1}$ value and heterosis components}

The possibility of prediction of the $\mathrm{F}_{1}$ value, GCA and SCA in the diallel was studied through correlations between $F_{1}$ and mid-parent, $F_{1}$ and GCA, general heterosis and GCA, general heterosis and per se value of parents $\left(\mathrm{v}_{\mathrm{i}}\right), \mathrm{F}_{1}$ value and the Hanson and Casas distance $\left(R^{2}{ }_{i j}\right)$, specific heterosis and $R^{2}{ }_{i j}$.

\subsection{Comparative studies of $F_{1}$ and $F_{2}$, and $\mathrm{DH}$ lines}

For traits where mid-parent heterosis was significant, $\mathrm{F}_{2}$ was also compared to the parents. Finally, the scaling test $\mathrm{C}=2 \mathrm{~F}_{2}-\mathrm{F}_{1}-\overline{\mathrm{P}}=0$ was used to detect non-additivity [28]. Such a test has been developed to test epistasis. However, epistasis is the cause of significance of this test only if there is no competition. Competition can generate interactions between genes, homologous or not, among different genotypes $[9,10]$; in that case, it can simulate epistasis. Therefore, even in the absence of true dominance and true epistasis, the scaling test $\mathrm{C}=0$ can be significant due to competition. The comparison of the average of all DH lines to the mid-parent value is also a test for non-additivity. As this test is not affected by inter-genotypic competition, it will detect more probably the effect of epistasis.

\section{Results}

\section{1. $F_{1}$ means, parental and specific heterosis}

Heterosis was low on average. The more affected traits were harvest index $(13.5 \%)$, main ear grain weight $(13 \%)$, ear length $(8.1 \%)$, straw height $(8.6 \%)$ and thousand grain weight $(6.9 \%)$ (table $I I$ ). For grain yield, the average of all $\mathrm{F}_{1}$ was equal to the average of parents. Average mid-parent heterosis was also near zero for number of ears, internode number and heading date. It was negative for straw yield $(-11.2 \%)$ and ear number per plant $(-15.3 \%)$. This means a 'dominance' of the low yielding parent. In terms of the best parent, the results showed that for several traits the $F_{1}$ were, on average, less than the best parent.

However, there was a great variation between crosses for most of the traits except straw yield and ear number per plant for which no difference appeared among crosses. For the grain yield, the greater heterosis was $25.8 \%$ in comparison to the mid-parent and $19.6 \%$ in comparison to the best parent. Only one hybrid (Jaidor $\times$ Prato), showed a yield slightly higher $(3.2 \%)$ than that of the best cultivar used in this trial, Prato. The best hybrids involved parents which were highly geographically distant, i.e. from France and USA. Reciprocal effects were never significant whatever the traits. Considering only traits for which differences among crosses were significant, i.e. except for ear number, GCA was always highly significant. SCA was generally less significant and non-significant for resistance to powdery mildew (table III). Except for grain and straw yield, percentages of explained variation for GCA were higher than 
Table II. Mid-parent heterosis in the $8 \times 8$ diallel.

\begin{tabular}{lcrrr}
\hline Traits & & \multicolumn{2}{c}{ Heterosis \% } \\
\cline { 4 - 4 } & & $\overline{\mathrm{F}}_{1}-\overline{\mathrm{P}}$ & $\left(\overline{\mathrm{F}}_{1}-\overline{\mathrm{P}}\right) / \overline{\mathrm{P}}$ Ave $\left(\mathrm{F}_{1 \mathrm{ij}}-\overline{\mathrm{P}}_{\mathrm{ij}}\right) / \overline{\mathrm{P}}_{\mathrm{ij}}{ }^{1}$ \\
\hline Grain yield & (g/plant) & $-0.2 \mathrm{~ns}$ & -1.1 & -0.7 \\
Straw yield & (g/plant) & $3.2^{* *}$ & -11.2 & -10.0 \\
Harvest index & & $0.05^{* * *}$ & 13.5 & 14.0 \\
Ear number per plant & & $-1.7^{* * *}$ & -15.3 & -13.9 \\
Main ear grain weight & $(\mathrm{g})$ & $0.3^{* * *}$ & 13.0 & 13.3 \\
Number of grains per ear & & $3.4 \mathrm{~ns}$ & 5.1 & 5.2 \\
Thousand grain weight & $(\mathrm{g})$ & $3.0^{* * *}$ & 6.9 & 2.8 \\
Ear length & $(\mathrm{cm})$ & $0.7^{* * *}$ & 8.4 & 9.8 \\
Straw height & $(\mathrm{cm})$ & $-0.14^{* * *}$ & 8.7 & -1.5 \\
Internode number & & $-0.2 \mathrm{~ns}$ & -1.6 & -0.2 \\
Heading date & (day) & $3.4^{*}$ & -0.2 & 8.8 \\
Mildew resistance & & & 8.6 &
\end{tabular}

$*, * *, * *$ Significant at $0.05,0.01,0.001$, respectively.

${ }^{1}$ Ave $\left(\mathrm{F}_{1 \mathrm{ij}}-\overline{\mathrm{P}}_{\mathrm{ij}}\right) / \overline{\mathrm{P}}_{\mathrm{ij}}$ means the average of the relative heterosis of each cross $i j$.

Table III. F- statistics from the analysis of variance of the $8 \times 8$ diallel according to Griffing method 3 .

\begin{tabular}{|c|c|c|c|c|}
\hline \multirow[b]{2}{*}{ Traits } & \multirow[t]{2}{*}{ GCA } & \multirow[t]{2}{*}{ SCA } & \multicolumn{2}{|c|}{ Reciprocal effects } \\
\hline & & & general & specific \\
\hline Grain yield & $4.7 * * *$ & $2.5^{* *}$ & $0.1 \mathrm{~ns}$ & $0.2 \mathrm{~ns}$ \\
\hline Straw yield & $3.9 * * *$ & $2.3 * *$ & $0.8 \mathrm{~ns}$ & $0.4 \mathrm{~ns}$ \\
\hline Harvest index & $2.9^{* *}$ & $1.3 \mathrm{~ns}$ & $0.8 \mathrm{~ns}$ & $0.8 \mathrm{~ns}$ \\
\hline Ear number per plant & $1.7 \mathrm{~ns}$ & $1.2 \mathrm{~ns}$ & $1.2 \mathrm{~ns}$ & $0.8 \mathrm{~ns}$ \\
\hline Main ear grain weight & $24.0 * * *$ & $3.2 * * *$ & $1.1 \mathrm{~ns}$ & $1.0 \mathrm{~ns}$ \\
\hline Number of grains per ear & $50.5 * * *$ & $11.2 * * *$ & $1.1 \mathrm{~ns}$ & $1.1 \mathrm{~ns}$ \\
\hline Thousand grain weight & $32.2 * * *$ & $3.9 * * *$ & $0.8 \mathrm{~ns}$ & $1.3 \mathrm{~ns}$ \\
\hline Ear length & $21.0 * * *$ & $4.5 * * *$ & $4.3 * *$ & $0.6 \mathrm{~ns}$ \\
\hline Straw height & $39.5 * * *$ & $4.5 * * *$ & $0.6 \mathrm{~ns}$ & $0.9 \mathrm{~ns}$ \\
\hline Internode number & $23.7 * * *$ & $2.4 * *$ & $3.1 * *$ & $1.7 \mathrm{~ns}$ \\
\hline Heading date & $46.4 * * *$ & $5.5 * * *$ & $1.7 \mathrm{~ns}$ & $1.3 \mathrm{~ns}$ \\
\hline Mildew resistance & $48.9 * * *$ & $0.7 \mathrm{~ns}$ & $0.5 \mathrm{~ns}$ & $0.8 \mathrm{~ns}$ \\
\hline
\end{tabular}

$*, * *, * *$ Significant at $0.05,0.01,0.001$, respectively; ns: non significant.

those for SCA, showing a more important role of GCA than SCA in the variation among crosses (table IV). From this criterion resistance to mildew and thousand grain weight appeared to be the most additive traits, whereas grain and straw yield are the least additive. The greater mid-parent heterosis and SCA values were associated with crosses involving at least a low performing parent, mainly 
for grain yield, harvest index, straw height, ear length and internode number.

Some parents, for some traits, have a high GCA associated with a low variation in SCA (data not shown). Such a behaviour may be due to favourable dominant genes. This is the case for Jaidor for the resistance to mildew, Motan for ear length,

Table IV. Variation components for combining ability in the $8 \times 8$ diallel.

\begin{tabular}{lccc}
\hline Traits & GCA $^{1}$ & SCA $^{2}$ & GCA/SCA \\
\hline Grain yield & 17.8 & 22.3 & 0.8 \\
Straw yield & 17.1 & 28.9 & 0.6 \\
Harvest index & $2.910^{-3}$ & $1.4610^{-3}$ & 2.0 \\
Ear number per plant & 0.58 & 0.49 & 1.2 \\
Main ear grain weight & 0.46 & 0.17 & 2.7 \\
Number of grains per ear & 261.5 & 170.3 & 1.5 \\
Thousand grain weight & 108.1 & 4.1 & 26.2 \\
Ear length & 0.98 & 0.60 & 1.6 \\
Straw height & 146.5 & 47.6 & 3.1 \\
Internode number & 0.27 & 0.05 & 5.3 \\
Heading date & 42.2 & 7.9 & 5.3 \\
Mildew resistance & 462.6 & 5.9 & 77.4 \\
\hline
\end{tabular}

$12 \Sigma \mathrm{g}_{\mathrm{i}}^{2} / 7$.

$2 \Sigma \mathrm{s}_{\mathrm{ij}}^{2} / 20$.
Ensenada for thousand grain weight, and Prato for grain yield and grain weight from main ear.

\subsection{Determination of the $F_{1}$ value and heterosis components}

\subsubsection{Relationships between $F_{1}$ value with mid-parent value, GCA and SCA}

Most of the correlations found between $F_{1}$ and mid-parent for different traits were positive and significant except for straw yield and harvest index (table $V$ ). However, except for thousand grain weight, internode number and heading date, the other correlations were lower than 0.70 . The midparent explained a maximum of $43.9 \%$ of the variation in the resistance to powdery mildew.

For all the traits given in table $V$, the $\mathrm{F}_{1}$ value was positively and highly significantly correlated with the GCA of parents. The correlation was higher than that with mid-parent and it is even significant for harvest index and straw yield, traits for which the correlation $F_{1}$-mid-parent was not significant. Except for grain yield and straw yield the correlations were equal or greater than 0.75 , i.e. GCA explained at least $56 \%$ of the variation among crosses. SCA explained about $64 \%$ of $F_{1}$ variation for grain and straw yield, $43 \%$ for straw

Table V. Determination of $F_{1}$ value and heterosis components in the $8 \times 8$ diallel.

\begin{tabular}{lllllll}
\hline Traits & & \multicolumn{5}{c}{ Correlation } \\
& $\mathrm{F}_{1}-\overline{\mathrm{P}}$ & $\mathrm{F}_{1}-\mathrm{GCA}$ & $\mathrm{F}_{1}-\mathrm{SCA}$ & $\mathrm{GCA}-\mathrm{v}_{\mathrm{i}}$ & $\mathrm{h}_{\mathrm{i}}-\mathrm{v}_{\mathrm{i}}$ & $\mathrm{s}_{\mathrm{ij}}-\mathrm{R}_{\mathrm{ij}}^{2}$ \\
\hline Grain yield & $0.58^{* * *}$ & $0.68^{* * *}$ & $0.78^{* * *}$ & $0.86^{* *}$ & $-0.02 \mathrm{~ns}$ & $-0.41 \mathrm{~ns}$ \\
Straw yield & $0.33 \mathrm{~ns}$ & $0.57^{* *}$ & $0.81^{* * *}$ & $0.58 \mathrm{~ns}$ & $-0.01 \mathrm{~ns}$ & $-0.36 \mathrm{~ns}$ \\
Harvest index & $0.33 \mathrm{~ns}$ & $0.76^{* * *}$ & $0.64^{* * *}$ & $0.37 \mathrm{~ns}$ & $-0.39 \mathrm{~ns}$ & $-0.25 \mathrm{~ns}$ \\
Ear number per plant & $0.13 \mathrm{~ns}$ & $0.29 \mathrm{~ns}$ & $0.69 \mathrm{~ns}$ & $0.21 \mathrm{~ns}$ & $-0.85^{*}$ & $-0.02 \mathrm{~ns}$ \\
Main ear grain weight & $0.55^{* * *}$ & $0.85^{* * *}$ & $0.46^{*}$ & $0.74^{*}$ & $-0.23 \mathrm{~ns}$ & $0.25 \mathrm{~ns}$ \\
Number of grains per ear & $0.59^{* *}$ & $0.82^{* * *}$ & $0.44^{*}$ & $0.72^{*}$ & $-0.08 \mathrm{~ns}$ & $0.01 \mathrm{~ns}$ \\
Thousand grain weight & $0.82^{* * *}$ & $0.89^{* * *}$ & $0.44^{*}$ & $0.96^{* * *}$ & $-0.01 \mathrm{~ns}$ & $0.04 \mathrm{~ns}$ \\
Ear length & $0.56^{* *}$ & $0.79^{* *}$ & $0.52^{* *}$ & $0.42 \mathrm{~ns}$ & $-0.51 \mathrm{~ns}$ & $-0.50^{* *}$ \\
Straw height & $0.61^{* * *}$ & $0.75^{* * *}$ & $0.66^{* * *}$ & $0.64 \mathrm{~ns}$ & $-0.61 \mathrm{~ns}$ & $-0.15 \mathrm{~ns}$ \\
Internode number & $0.74^{* * *}$ & $0.87^{* * *}$ & $0.49^{*}$ & $0.85^{* *}$ & $-0.51 \mathrm{~ns}$ & $0.15 \mathrm{~ns}$ \\
Heading date & $0.82^{* * *}$ & $0.91^{* * *}$ & $0.39^{*}$ & $0.95^{* * *}$ & $-0.26 \mathrm{~ns}$ & $0.05 \mathrm{~ns}$ \\
Mildew resistance & $0.64^{* * *}$ & $0.96^{* * *}$ & $0.26 \mathrm{~ns}$ & $0.71^{*}$ & $0.17 \mathrm{~ns}$ & $0.09 \mathrm{~ns}$
\end{tabular}

$*, * *, * * *$ Significant at $0.05,0.01,0.001$, respectively; ns: non significant 
height and less than $25 \%$ for other traits. The correlation $\mathrm{F}_{1}-\mathrm{SCA}$ was not significant for resistance to mildew.

\subsubsection{Relationships between per se value, GCA and parental heterosis}

The correlation between GCA and line per se value $\left(\mathrm{v}_{\mathrm{i}}\right)$ was significant for seven traits out of 11 (table $V$ ). It was not significant for straw yield, harvest index, plant height and ear length. For grain yield, thousand grain weight, internode number and heading date the per se value explains more than $70 \%$ of variation, while for main ear grain weight, grain number and resistance to powdery mildew it explained about $50 \%$ of total variation. The correlation between parental heterosis $\left(\mathrm{h}_{\mathrm{i}}\right)$ and per se value of parents was generally not significant.

\subsubsection{Relationships between SCA and Hanson and Casas distance}

The correlation between the Hanson and Casas distance $\left(R^{2}{ }_{i j}\right)$ and the $F_{1}$ value was not significant for all traits except for the internode number $\left(0.61^{* *}\right.$ ) (table $V$ ). The correlation between $\mathrm{R}^{2}$ ij and specific heterosis $\left(h_{i j}\right)$ was also not significant except for ear length $(-0.50 *)$.

\subsection{Inbreeding depression from $F_{1}$ to $F_{2}$}

This study was developed with crosses Motan/CM67, Prato/CM67 and Apizaco/Prato. The loss of heterosis in $\mathrm{F}_{2}$ is expected to be $50 \%$. For 11 cross and trait combinations for which the heterosis measured by the difference between $F_{1}$ and mid-parent was significant, five showed an inbreeding depression from $F_{1}$ to $F_{2}$ in agreement with expectation (table VI). This was the case for all traits exhibiting heterosis with the Apizaco $\times$ Prato cross. It was also the case for straw yield, harvest index and grain weight from main ear, whatever the cross. For the six significant situations, the depression in $\mathrm{F}_{2}$ was always greater than expected; this was in particular the case for grain yield for the two crosses Prato $\times$ CM67 and
Motan $\times$ CM67. The scaling test $\mathrm{C}=2 \mathrm{~F}_{2}-\mathrm{F}_{1}-\overline{\mathrm{P}}$ corresponds in fact to the comparison of observed to expected depression in $\mathrm{F}_{2}$. It was then significant for grain yield for Prato $\times$ CM67 and Motan $\times$ CM67, for grain number per ear and ear length for Prato $\times$ CM67, and for thousand grain weight and straw height for Motan $\times$ CM67. This means either a competition effect or epistasis or both.

\subsection{Comparison between $\mathrm{F}_{1}$ and $\mathrm{DH}$}

This study was developed from the cross Motan $\times$ CM67. The average of all DH lines was equal to mid-parent value only for straw yield, harvest index, number of ears and grain weight from main ear (table VII). For the eight other traits, the difference between the two averages was highly significant, showing a situation of non-additivity of locus effects, which can be due to epistasis or competition. This was in particular the case for grain yield. For five out of these traits, the difference was negative, showing a negative effect of recombination. However, a great variation was observed among DH lines. For most traits studied, DH lines statistically higher or equal to $F_{1}$ were obtained. However, for thousand grain weight, all the $\mathrm{DH}$ lines obtained are statistically lower than $F_{1}$.

\section{Discussion}

As a whole, the amount of heterosis for grain yield was relatively low in this experiment. Generally, greater heterosis was associated with a low mid-parent performance. The specific heterosis values obtained show a large variability for all the traits allowing the selection of superior $F_{1}$ hybrids. The best heterosis for grain yield, harvest index, thousand grain weight and ear length was given by the hybrids resulting from geographically different lines. This suggests a good gene complementarity between these cultivars. Johnson and Whittington [22] have already underlined that the divergence between parents (European cultivars $\times$ American cultivars) increases the level of heterosis. On the 
Table VI. Comparison of generation means $\mathrm{F}_{1}, \mathrm{~F}_{2}$ and $\overline{\mathrm{P}}$ for three crosses.

\begin{tabular}{|c|c|c|c|c|c|c|c|c|}
\hline Traits & Year & Cross ${ }^{1}$ & $\mathrm{~F}_{1}$ & $\mathrm{~F}_{1}-\overline{\mathrm{P}}$ & $\mathrm{F}_{1}-\mathrm{F}_{2}$ & $\left(\mathrm{~F}_{1}-\overline{\mathrm{P}}\right) / 2$ & $\mathrm{~F}_{2}-\overline{\mathrm{P}}$ & $\mathrm{C}^{2}$ \\
\hline $\begin{array}{l}\text { Grain yield } \\
\text { (g/plant) }\end{array}$ & $\begin{array}{l}1988 \\
1988 \\
1991\end{array}$ & $\begin{array}{l}\text { Pra } \times \text { CM67 } \\
\text { Api } \times \text { Pra } \\
\text { Mot } \times \text { CM } 67\end{array}$ & $\begin{array}{r}10.2 \\
6.2 \\
10.0\end{array}$ & $\begin{aligned} & 4.9 * * * \\
&-0.1 \mathrm{~ns} \\
& 0.5 \mathrm{~ns}\end{aligned}$ & $\begin{array}{l}4.4 \\
0.4 \\
2.9\end{array}$ & $\begin{array}{l}2.4 \\
0.0 \\
0.2\end{array}$ & $\begin{aligned} & 0.6 \mathrm{~ns} \\
- & 0.05 \mathrm{~ns} \\
- & 1.5 \mathrm{~ns}\end{aligned}$ & $\begin{array}{l}* * \\
\mathrm{~ns} \\
* * *\end{array}$ \\
\hline $\begin{array}{l}\text { Straw yield } \\
\text { (g/plant) }\end{array}$ & $\begin{array}{l}1988 \\
1988 \\
1991\end{array}$ & $\begin{array}{l}\text { Pra } \times \text { CM67 } \\
\text { Api } \times \text { Pra } \\
\text { Mot } \times \text { CM67 }\end{array}$ & $\begin{array}{r}12.0 \\
8.4 \\
8.1\end{array}$ & $\begin{array}{r}3.5 * * \\
-1.3 \mathrm{~ns} \\
-0.9 \mathrm{~ns}\end{array}$ & $\begin{array}{r}3.4 \\
-0.4 \\
0.1\end{array}$ & $\begin{array}{r}1.7 \\
-0.6 \\
-0.4\end{array}$ & $\begin{array}{r}0.1 \mathrm{~ns} \\
-0.4 \mathrm{~ns} \\
-1.0 \mathrm{~ns}\end{array}$ & $\begin{array}{l}\text { ns } \\
\text { ns } \\
\text { ns }\end{array}$ \\
\hline Harvest index & $\begin{array}{l}1988 \\
1988 \\
1991\end{array}$ & $\begin{array}{l}\text { Pra } \times \text { CM67 } \\
\text { Api } \times \text { Pra } \\
\text { Mot } \times \text { CM67 }\end{array}$ & $\begin{array}{l}0.46 \\
0.43 \\
0.49\end{array}$ & $\begin{array}{r}0.08 * * * \\
0.03 \mathrm{~ns} \\
-0.02 \mathrm{~ns}\end{array}$ & $\begin{array}{l}0.1 \\
0.0 \\
0.0\end{array}$ & $\begin{array}{r}0.04 \\
0.01 \\
-0.01\end{array}$ & $\begin{array}{r}0.03 \mathrm{~ns} \\
0.04 \mathrm{~ns} \\
-0.06 \mathrm{~ns}\end{array}$ & $\begin{array}{l}\text { ns } \\
\text { ns } \\
\text { ns }\end{array}$ \\
\hline $\begin{array}{l}\text { Main ear grain } \\
\text { weight }(\mathrm{g})\end{array}$ & $\begin{array}{l}1988 \\
1988 \\
1991\end{array}$ & $\begin{array}{l}\text { Pra } \times \text { CM67 } \\
\text { Api } \times \text { Pra } \\
\text { Mot } \times \text { CM67 }\end{array}$ & $\begin{array}{l}2.9 \\
2.6 \\
3.2\end{array}$ & $\begin{array}{l}1.1 \mathrm{~ns} \\
0.7 \mathrm{~ns} \\
1.4 \mathrm{~ns}\end{array}$ & $\begin{array}{l}0.8 \\
0.3 \\
0.9\end{array}$ & $\begin{array}{l}0.5 \\
0.3 \\
0.7\end{array}$ & $\begin{array}{l}0.3 \mathrm{~ns} \\
0.4 \mathrm{~ns} \\
0.4 \mathrm{~ns}\end{array}$ & $\begin{array}{l}\text { ns } \\
\text { ns } \\
\text { ns }\end{array}$ \\
\hline $\begin{array}{l}\text { Ear number } \\
\text { per plant }\end{array}$ & $\begin{array}{l}1988 \\
1988 \\
1991\end{array}$ & $\begin{array}{l}\text { Pra } \times \text { CM67 } \\
\text { Api } \times \text { Pra } \\
\text { Mot } \times \text { CM67 }\end{array}$ & $\begin{array}{l}4.6 \\
3.3 \\
3.8\end{array}$ & $\begin{array}{r}1.0 \mathrm{~ns} \\
-0.7 \mathrm{~ns} \\
-1.9 \mathrm{~ns}\end{array}$ & $\begin{array}{r}0.9 \\
-0.4 \\
-0.6\end{array}$ & $\begin{array}{r}0.5 \\
-0.3 \\
-1.0\end{array}$ & $\begin{array}{r}0.0 \mathrm{~ns} \\
-0.3 \mathrm{~ns} \\
-1.4 \mathrm{~ns}\end{array}$ & $\begin{array}{l}\text { ns } \\
\text { ns } \\
\text { ns }\end{array}$ \\
\hline $\begin{array}{l}\text { Grain number } \\
\text { per ear }\end{array}$ & $\begin{array}{l}1988 \\
1988 \\
1991\end{array}$ & $\begin{array}{l}\text { Pra } \times \text { CM67 } \\
\text { Api } \times \text { Pra } \\
\text { Mot } \times \text { CM67 }\end{array}$ & $\begin{array}{l}67.8 \\
63.2 \\
62.1 \\
\end{array}$ & $\begin{array}{l}16.8 * * * \\
11.9 * \\
17.7 * * *\end{array}$ & $\begin{array}{r}13.7 \\
7.3 \\
2.9\end{array}$ & $\begin{array}{l}8.4 \\
6.0 \\
8.8\end{array}$ & $\begin{array}{c}3.1 \mathrm{~ns} \\
4.7 \mathrm{~ns} \\
14.8^{* * *}\end{array}$ & $\begin{array}{l}* \\
\text { ns } \\
\text { ns }\end{array}$ \\
\hline $\begin{array}{l}\text { Thousand grain } \\
\text { weight }(\mathrm{g})\end{array}$ & $\begin{array}{l}1988 \\
1988 \\
1991\end{array}$ & $\begin{array}{l}\text { Pra } \times \text { CM67 } \\
\text { Api } \times \text { Pra } \\
\text { Mot } \times \text { CM67 }\end{array}$ & $\begin{array}{l}43.0 \\
39.5 \\
51.2\end{array}$ & $\begin{array}{c}10.1 * * * \\
2.60 \mathrm{~ns} \\
11.7 * * *\end{array}$ & $\begin{array}{r}6.0 \\
0.0 \\
14.0\end{array}$ & $\begin{array}{l}5.0 \\
1.3 \\
5.8\end{array}$ & $\begin{array}{r}4.1 \mathrm{~ns} \\
2.6 \mathrm{~ns} \\
-2.2 \mathrm{~ns}\end{array}$ & $\begin{array}{l}\text { ns } \\
\text { ns } \\
* * *\end{array}$ \\
\hline $\begin{array}{l}\text { Straw height } \\
(\mathrm{cm})\end{array}$ & $\begin{array}{l}1988 \\
1988 \\
1991\end{array}$ & $\begin{array}{l}\text { Pra } \times \text { CM } \\
\text { Api } \times \text { Pra } \\
\text { Mot } \times \text { CM }\end{array}$ & $\begin{array}{l}77.6 \\
76.7 \\
91.7\end{array}$ & $\begin{array}{l}8.8^{* * * *} \\
3.8 \mathrm{~ns} \\
4.9 \mathrm{~ns}\end{array}$ & $\begin{array}{r}0.1 \\
-2.6 \\
12.4\end{array}$ & $\begin{array}{l}4.4 \\
1.9 \\
2.5\end{array}$ & $\begin{array}{r}8.7 \mathrm{~ns} \\
1.2 \mathrm{~ns} \\
-7.3 * * *\end{array}$ & $\begin{array}{l}\mathrm{ns} \\
\mathrm{ns} \\
* * *\end{array}$ \\
\hline Ear length $(\mathrm{cm})$ & $\begin{array}{l}1988 \\
1988 \\
1991\end{array}$ & $\begin{array}{l}\text { Pra } \times \text { CM67 } \\
\text { Api } \times \text { Pra } \\
\text { Mot } \times \text { CM67 }\end{array}$ & $\begin{array}{l}8.3 \\
7.4 \\
7.4\end{array}$ & $\begin{array}{l}1.5^{* * * *} \\
0.5^{*} \\
1.3 \mathrm{~ns}\end{array}$ & $\begin{array}{r}1.4 \\
0.6 \\
-0.0\end{array}$ & $\begin{array}{l}0.8 \\
0.3 \\
0.6\end{array}$ & $\begin{array}{r}0.2 \mathrm{~ns} \\
-0.0 \mathrm{~ns} \\
1.3 \mathrm{~ns}\end{array}$ & $\begin{array}{l}* * \\
\mathrm{~ns} \\
\mathrm{~ns}\end{array}$ \\
\hline $\begin{array}{l}\text { Internode } \\
\text { number }\end{array}$ & $\begin{array}{l}1988 \\
1988 \\
1991\end{array}$ & $\begin{array}{l}\text { Pra } \times \text { CM } \\
\text { Api } \times \text { Pra } \\
\text { Mot } \times \text { CM }\end{array}$ & $\begin{array}{l}6.7 \\
6.3 \\
5.7\end{array}$ & $\begin{array}{r}0.3 \mathrm{~ns} \\
-0.2 \mathrm{~ns} \\
-0.3 \mathrm{~ns}\end{array}$ & $\begin{array}{l}0.2 \\
0.2 \\
0.1\end{array}$ & $\begin{array}{r}0.1 \\
-0.1 \\
-0.1\end{array}$ & $\begin{array}{r}0.1 \mathrm{~ns} \\
0.2 \mathrm{~ns} \\
-0.4 \mathrm{~ns}\end{array}$ & $\begin{array}{l}\text { ns } \\
\text { ns } \\
\text { ns }\end{array}$ \\
\hline
\end{tabular}

$*$,**,*** Significant at $0.05,0.01,0.001$, respectively; ns: non significant.

${ }^{1}$ Pra $=$ Prato, Mot $=$ Motan.

${ }^{2} \mathrm{C}=2 \mathrm{~F}_{2}-\mathrm{F}_{1}-\overline{\mathrm{P}}$

whole, it appears that the mid-parent heterosis for grain weight from main ear was higher than that for yield components. Such results are in accordance with those of Lefort-Buson [25] on rape and with those found on bread wheat $[1,20,31,35]$. This superiority of yield heterosis might result from accumulation of heterosis effects observed for the various simple traits such as grain number 
Table VII. Comparison of generation means $\mathrm{F}_{1}, \mathrm{~F}_{2}$ and DH for the cross Motan $\times$ CM64.

\begin{tabular}{lcccccc}
\hline Traits & $\mathrm{F}_{1}$ & $\mathrm{~F}_{2}$ & $\overline{\mathrm{HD}}$ & $\mathrm{HD}-\overline{\mathrm{P}}$ & $\mathrm{F}_{1}-\overline{\mathrm{HD}}$ & $\mathrm{F}_{2}-\overline{\mathrm{HD}}$ \\
\hline Grain yield (g/plant) & 10.0 & 7.0 & 6.7 & $-2.7^{* *}$ & $3.3^{* * *}$ & $1.2 \mathrm{~ns}$ \\
Straw yield (g/plant) & 8.1 & 8.0 & 8.7 & $0.3 \mathrm{~ns}$ & $-0.6 \mathrm{~ns}$ & $-0.76 \mathrm{~ns}$ \\
Harvest index & 0.49 & 0.45 & 0.42 & $-0.10 \mathrm{~ns}$ & $0.08^{* *}$ & $0.04 \mathrm{~ns}$ \\
Ear number per plant & 3.8 & 4.3 & 4.8 & $-0.9 \mathrm{~ns}$ & $-0.9 \mathrm{~ns}$ & $-0.4 \mathrm{~ns}$ \\
Main ear grain weight (g) & 3.2 & 2.2 & 1.8 & $0.09 \mathrm{~ns}$ & $1.3^{* * *}$ & $0.4^{* *}$ \\
Grain number per ear & 62.1 & 59.2 & 54.5 & $10.1^{* * *}$ & $7.6^{* *}$ & $4.6 \mathrm{~ns}$ \\
Thousand grain weight (g) & 51.2 & 37.2 & 33.9 & $-5.5^{* * *}$ & $17.2^{* * *}$ & $3.2 \mathrm{~ns}$ \\
Ear length (cm) & 7.3 & 7.4 & 7.4 & $1.3^{* * *}$ & $-0.0 \mathrm{~ns}$ & $0.0 \mathrm{~ns}$ \\
Straw height (cm) & 91.7 & 79.3 & 75.2 & $-11.5^{* * *}$ & $16.4^{* * *}$ & $4.1^{*}$ \\
Internode number & 5.7 & 5.6 & 5.5 & $-0.5^{* * *}$ & $0.2 \mathrm{~ns}$ & $0.1 \mathrm{~ns}$ \\
Heading date (days) & 117.3 & 117.3 & 122.4 & $2.5 * *$ & $-5.0^{* * *}$ & $-5.0^{* * *}$ \\
Mildew resistance & 44.9 & 44.9 & 44.8 & $-18.2^{* * *}$ & $0.2 \mathrm{~ns}$ & $0.0 \mathrm{~ns}$ \\
\hline
\end{tabular}

$*, * *, * * *$ Significant at $0.05,0.01,0.001$, respectively; ns: non significant.

per ear and thousand grain weight. In this case, the improvement of complex traits such as grain yield could be obtained by the improvement of the yield components which display more additivity.

The correlation between $F_{1}$ and mid-parent value was significant for different traits. However, the mid-parent value did not allow prediction of the $F_{1}$ value with enough accuracy for grain yield. The fact that the correlation between $F_{1}$ and GCA was higher than the correlation between $\mathrm{F}_{1}$ and the mid-parent, shows that dominance or epistatic effects may exist. In the case of additivity, it can also be the result of a greater accuracy on GCA than on the parental value. This was in particular clearly the case for mildew resistance, a trait which does not show SCA, but also for main ear grain weight and grain number, two traits for which the correlation $\mathrm{F}_{1}-\mathrm{SCA}$ was low. In fact, such an effect of low accuracy on per se value must affect more or less all traits, even those showing a preponderant role of SCA, such as grain and straw yield which are also traits known to be greatly influenced by environment. It appears then, that grain weight of the main ear and its components (grain number and thousand grain weight), heading date and resistance to mildew are the more additive traits and grain and straw yield are the less addi- tive. As a consequence for the plant breeder, it will be possible to select the parent on the basis of their earliness and grain yield components of main ear.

Several arguments are in favour of a possible fixation of heterosis. Indeed, the role of dominance appeared at different levels. First, the coexistence of a high additivity with heterosis, with a high $\mathrm{F}_{1}$-mid-parent correlation, could be due to partial to complete dominance. The fact that large SCA values were associated with crosses involving at least a low performing parent is also in favour of dominance. Furthermore, for several traits, it was observed that parents with good GCA transmitted their quality to their offspring, probably because of dominant genes. Finally, the best argument in favour of possible fixation of heterosis is the fact that for most of the traits, the best $F_{1}$ was nearly equal to the best parent. In the presence of a major role of dominant genes, a negative correlation between parental heterosis and per se value was expected. Such a correlation has already been estimated as significantly negative in different species $[3,11,19]$. In our experiment, the correlation was negative but non-significant; the non-significance perhaps due to a lack of accuracy at the level of per se value. 
The study of inbreeding depression from the $F_{1}$ to $\mathrm{F}_{2}$ shows that, for some traits (grain yield, thousand grain weight, number of grains per ear, plant height), in competition conditions, the heterosis can be reduced by more than one half, which is what is expected with additivity of locus effects. Such deviations from expected values can be due to epistasis or to competition. It is probable that in our condition of high density, intergenotypic competition may have played a great role at the $F_{2}$ level. Indeed, a performance of a plant depends on two types of parameters: its producer or direct effect and the associate effects of its neighbours [9, $10,13]$. As a plant is simultaneously producer and partner, with a positive association between direct and associate effect, i.e. when the more productive plants are also the more competitive, the value of the $F_{2}$ can be greater than expected. On the contrary, if there is a negative association between the two parameters, the value of the $F_{2}$ can be lower than expected. This could be the case with high difference in tillering, tillering ability being a trait related to aggressiveness of forage grasses very often negatively related to biomass in dense sward. It seems that it was such a situation in our experiment at least in the Motan $\times$ CM67 cross. In this cross, the $F_{2}$ plants were shorter than expected. This can be explained by a negative correlation between vegetative tillering and plant height. Then, by competition, high tillering/low yielding plants tend to dominate low tillering/high yielding plants, with the correlated negative effect on thousand grain weight, because there was a positive correlation between thousand kernel weight and plant height. In fact this may be due to difference in earliness and to a drought stress which affected late plants. In such conditions, high tillering/low yielding plants were late and the low tillering/high yielding ones were early. For the other cross, Prato $\times$ CM67, the situation was not so clear because $F_{2}$ plants tended to be taller than expected, although not significantly; however, grain yield, ear length and grain number per ear were lower than expected. In this situation, competition and epistasis could explain the observed results. Our results are not in accordance with those of Singh and Mishra [36] who obtained in one hybrid con- siderable heterosis and a very low inbreeding depression for grain yield in $F_{2}$. However, they show that deviations from expected depression depend on the cross and on environmental conditions which can affect competitive ability of genotypes.

The comparison of DH lines to the mid-parent in one cross showed that for several important traits recombination has an unfavourable effect. As there is no intergenotypic competition within $\mathrm{F}_{1}$ and $\mathrm{DH}$ plot, i.e. no competition between different genotypes, such a result may be due to epistatic effects. This means that recombination has destroyed some genic equilibrium. The comparison between the average of $\mathrm{DH}$ lines and mid-parent values is a more powerful test of epistasis than the test $\mathrm{C}=2 \mathrm{~F}_{2}-\mathrm{F}_{1}-\overline{\mathrm{P}}$. This confirms the result from this test for grain yield, thousand grain weight and plant height. The unfavourable effect of recombination appears clearly at the $\mathrm{F}_{2}$ level but is not so obvious at the DH level, owing to heterozygosity. In addition, for the Motan $\times$ CM67 cross, epistasis must be also considered superimposed with a competition effect. Strong epistatic effects have also already been detected by Goldringer et al. [14], in wheat, by studying genetic variance components among DH lines. To understand the unfavourable effect of recombination it is necessary to consider simultaneously epistasis and the distribution of genes between the parents. According to Snape and Simpson [37], this unfavourable effect could be due to duplicate epistasis and excess of coupling or to complementary epistasis and excess of repulsion. In such a case, it will be better to derive DH from generations after $F_{1}$. Recombination after the first meiosis will tend to correct unfavourable effects.

In spite of such an unfavourable effect of haplodiploidization, it appears that the genetic advantage obtained in $F_{1}$ can be fixed by the doubledhaploid method. For all traits, except thousand grain weight, it was possible to observe some lines equal to the $F_{1}$. This tends to confirm our conclusion from the diallel analysis that heterosis will be fixable. Such a conclusion was already derived by Kasha [23], Reinbergs et al. [33] and Fedak [7], from the study of DH lines. However, the probabil- 
ity of transgression depends on several parameters: the difference between the $F_{1}$ value and the $\mathrm{DH}$ mean, the variance among $\mathrm{DH}$ lines and the heritability values concerning the $\mathrm{DH}$ lines. Considering the variance, again the effect of distribution of genes among the parents must be considered, even without epistasis. With an excess of coupling, the variance among DH lines will be maximum with haplodiploidisation at the $F_{1}$ level, and if there is an excess of repulsion it will be maximum with haplodiploidisation in later generations. Taking into account the quite different origins of the parents it is probable that, in our cross, there was an excess of coupling. Then, haplodiploidisation at the $\mathrm{F}_{1}$ level will be justified. The study of the probability of transgression shows that it would be necessary to study at least 100 to 150 DH lines to have some chance of detecting several good lines (2-5).

In the material studied, it can clearly be seen that $F_{1}$ superiority is not large enough to produce hybrid seed profitably. Rousset [34], Brears et al. [2] and Oury et al [30] consider that about $12 \%$ gain is required to compensate for the high cost of hybrid seed production. In the material studied, it does not appear justified to develop $F_{1}$ hybrids. Even if there was a sufficient advantage of $F_{1}$ there does not appear to be any benefit in using $F_{2}$, perhaps owing to a strong negative effect of competition. Then, taking into account the results of the present study, one of the most efficient strategies of variety development in barley could be to develop doubled-haploid lines which allow the development of lines as good as $F_{1}$.

Acknowledgements: We are very grateful to $\mathrm{Dr}$ Felicity Vear and Louis Jestin, Inra (Clermont-Ferrand, France) for their helpful comments on the manuscript.

\section{References}

[1] Bhadouria S.S., Singh K.P., Shrivastava P.S., Heterosis in common wheat (Triticum aestivum L.), JNKVV (Jawaharlal Nehru Krishi Vishwa Vidyalaya) Res. J. 10 (1976) 219-225.

[2] Brears T., Hydon A.G., Bingham J., An assessment of the feasibility of producing $F_{1}$ and $F_{2}$ hybrids for the UK, Proc. 7th Int. Wheat Genet. Symp., 1988, pp. 1057-1062.

[3] Bulmer M.G., The Mathematical Theory of Quantitative Genetics, Clarendon Press, Oxford, 1980.

[4] Charcosset A., Gallais A., Intérêt des marqueurs en sélection, in: de Vienne D. (Ed.), Les marqueurs moléculaires en génétique et biotechnologies végétales, Inra, Paris, 1998, pp. 138-159.

[5] Eberhart S.A., Gardner C.O., A general model for genetic effects, Biometrics 22 (1966) 864-881.

[6] Fedak G., Fejer S.O., Yield advantage in $F_{\text {, }}$ hybrids between spring and winter barley, Can. J. Plant Sci. 55 (1975) 547-553.

[7] Fedak G., Evaluation of doubled haploids in barley, Z. Pflanzenzüchtg 76 (1976) 147-151.

[8] Foster C.A., Fothergill M., Breeding $F_{1}$ hybrid barley, in: Barley genetics. IV, Proceedings of the fourth international barley genetics symposium, Edinburgh, 22-29 July, 1981, pp. 766-771.

[9] Gallais A., Sur quelques aspects de la compétition en amélioration des plantes, Ann. Amélior. Plant. 25 (1975) 51-64.

[10] Gallais A., Théorie de la sélection en amélioration des plantes, Collection sciences agronomiques, Masson, Paris, 1990.

[11] Geiger H.H., Schnell F.W., Wahle G., Relationship among line performance, heterosis and combining ability. II. First results, 3rd Meeting of the Eucarpia section 'Biometrics in Plant Breeding', 1997.

[12] Griffing B., Concept of general and specific combining ability in relation to diallel crossing systems, Aust. J. Biol. Sci. 9 (1956) 463-493.

[13] Griffing B., Selection in reference to biological groups. I- Individual and group selection applied to population of unordered groups, Aust. J. Biol. Sci. 20 (1967) 127-139.

[14] Goldringer I., Brabant P., Gallais A., Estimation of additive and epistatic genetic parameters in a population of doubled haploids lines in wheat, Heredity 79 (1997) 60-71.

[15] Goldringer I., Brabant P., Kempton R., Adjustment for competition between genotypes in single row trials of winter wheat, Plant Breed. 122 (1994) 294-300.

[16] Guo P., Zhang J. Gan W., Cai M., Methods of distance analysis and heterosis, Acta Genet. Sin. 16 (1989) 97-104.

[17] Hallauer A.R., Miranda J.B., Quantitative genetics in maize breeding, Iowa State University Press, Ames, 1981. 
[18] Hanson W.D., Casas E., Spatial relationship among eight populations of Zea mays L, utilizing information from a diallel mating design, Biometrics 24 (1968) 867-880.

[19] Hébert Y., Gallais A., Heterosis and genetic variation for quantitative characters in a $12 \times 12$ diallel mating design in maize, in: Proc. 6th Meeting of Eucarpia section 'Biometrics in Plant Breeding', Univ. Birmingham, 1986, pp. 140-142.

[20] Jatasra D.S., Paroda R.S., Waldia R.S., Hybrid vigor in an 8 parent diallel cross for yield and its components in wheat, Haryana Agric. Univ. J. Res. 10 (1980) 317-323.

[21] Jestin L., Quelques réflexions sur les possibilités de développement de variétés hybrides chez les orges, Inra, Clermont-Ferrand, 1987.

[22] Johnson G.F., Whittington W.J., Inheritance of yield components and yield in relation to evidence for heterosis in $F_{1}$ barley hybrids, Euphytica, 27 (1978) 587-591.

[23] Kasha K.J., Song L.S.P., Park S.J., Reinbergs E., Fixation of heterosis: comparison of $F_{1}$ hybrids with their respective homozygous lines developed using doubled haploid procedures, Cer. Res. Com. 5 (1977) 205-214.

[24] Kratochvil R.J., Sammons D.J., A comparison of soft red winter wheat $F_{2}$ populations, their $F_{1}$ hybrids, and parents, J. Prod. Agric. 3 (1990) 363- 367.

[25] Lefort-Buson M., Heterosis chez le colza oléagineux (Brassica napus L.): analyse génétique et prédiction, thèse, université de Paris-Sud; Orsay, 1986.

[26] Lefort-Buson M., de Vienne D., Les distances génétiques. Estimations et applications, Inra, Versailles, 1985.

[27] Marchais L., Une analyse génétique chez le petit mil pénicillaire à l'aide de la distance $\mathrm{R}$ de Hanson et Casas, Ann. Amélior. Plant. 28 (1978) 165-193.
[28] Mather K., Jinks J.L., Introduction to Biometrical Genetics, Chapman and Hall, London, 1977.

[29] Moll R.H., Lonnquist J.H., Fortuno Velez J., Johnson E.C., The relationship of heterosis and genetic distance in maize, Genetics 52 (1965) 139-144.

[30] Oury F.X., Brabant P., Pluchard P., Berard P., Rousset M., Etude multilocale de blés hybrides: niveaux d'hétérosis et élaboration du rendement, Agronomie 10 (1990) 735-748.

[31] Perenzin M., Corbellini M., Borghi B., Growth analysis of ten bread wheat hybrids (Triticum aestivum) produced with a chemical hybridizing agent, Genet. Agrar. 41 (1987) 163-172.

[32] Picard B., Branlard G., Oury F.X., Bérard P., Rousset M., Etude de la diversité génétique du blé tendre, II. Application à la prédiction de l'hétérosis, Agronomie 12 (1992) 683-690.

[33] Reinbergs E., Park K.J., Song L.S.P., Early identification of superior barley crosses by the doubled haploid technique, Z. Pflanzenzücht. 76 (1976) 215-224.

[34] Rousset M., Les blés hybrides sortent du laboratoire, La Recherche 17 (1986) 86-89.

[35] Singh I., Behl R.K., Genetic divergence in relation to combining ability and transgression in wheat, $\mathrm{J}$. Genet. Breed. 45 (1991) 147-150.

[36] Singh T., Mishra D.P., Heterosis and inbreeding depression in bread wheat (Triticum aestivum L.EM, THELL), Theor. Appl. Genet. 67 (1990) 143-148.

[37] Snape J.W., Simpson E., The genetical expectations of doubled haploid lines derived from different filial generations, Theor. Appl. Genet. 60 (1981) 123-128.

[38] Xiao J., Li J., Yuan L., McCouch S.R., Tanksley S.D., Genetic diversity and its relationship to hybrid performance and heterosis in rice as revealed by PCRbased markers, Theor. Appl. Genet. 92 (1996) 637-643. 